\title{
UJI AKTIVITAS ANTIBAKTERI EKSTRAK ETANOL DAUN KALANDUYUNG (Guazuma ulmifolia Lam.) TERHADAP PERTUMBUHAN STAPHYLOCOCCUS AUREUS DENGAN METODE DIFUSI CAKRAM (KIRBY-BAUER)
}

\section{Antibacterial Activity Test of Ethanol Extract from Kalanduyung Leaf (Guazuma ulmifolia Lam.) on Staphylococcus aureus Growth with Difussion Method (Kirby-Bauer)}

\author{
*Adelgrit Trisia, Regina Philyria, \& Angeline Novia Toemon \\ Medical Study Program, Universitas Palangka Raya, Yos Sudarso Kampus Tunjung Nyaho St., Palangka Raya, \\ Indonesia \\ *e-mail : adelgrit trisia@yahoo.com
}

\begin{abstract}
ABSTRAK
Pneumonia merupakan infeksi akut pada parenkim paru, bronkiolus respiratorius dan alveoli, yang dapat disebabkan oleh bakteri Staphylococcus aureus. Kalanduyung (Guazuma ulmifolia Lam.) merupakan tumbuhan herbal Kalimantan Tengah yang dipercaya masyarakat memiliki banyak khasiat salah satunya untuk pneumonia. Mengetahui adanya aktivitas antibakteri ekstrak etanol daun Kalanduyung terhadap pertumbuhan Staphylococcus aureus. Jenis penelitian ini adalah penelitian eksperimental dengan rancangan Post test-only control group design. Ekstrak etanol daun Kalanduyung pada konsentrasi $20 \%, 40 \%, 60 \%$, dan $80 \%$ diuji aktivitas antibakterinya terhadap pertumbuhan Staphylococcus aureus menggunakan metode difusi cakram Kirby-Bauer dengan Amoksisilin sebagai kontrol positif dan dimetil sulfoksida 10\% sebagai kontrol negatif. Data penelitian dianalisis secara statistik menggunakan uji One Way Anova. Ekstrak etanol daun Kalanduyung pada konsentrasi $20 \%$, 40\%, 60\%, dan $80 \%$ dapat menghambat pertumbuhan bakteri Staphylococcus aureus dengan rata-rata zona hambat masing-masing yaitu $6,875 \mathrm{~mm}, 8,5 \mathrm{~mm}, 10,175 \mathrm{~mm}$, dan 14,925 mm. Ekstrak etanol daun Kalanduyung dapat menghambat pertumbuhan bakteri Staphylococcus aureus.
\end{abstract}

Kata kunci: Staphylococcus aureus, daun Kalanduyung (Guazuma ulmifolia Lam.), Cakram Kirby-Bauer

\begin{abstract}
Pneumonia is an infectious of lung parenchyma, respiratory bronchioles, and alveolus, caused by Staphylococcus aureus. Kalanduyung (Guazuma ulmifolia Lam.) is an herb plant from Central Borneo which people believe has many benefits, which one is curing pneumonia. To identify the antibacterial activity from ethanol extract of Kalanduyung leaves to the Staphylococcus aureus growth. This research was an experimental with post test-only control group design. Ethanol extract of Kalanduyung leaves in $20 \%, 40 \%, 60 \%$, and $80 \%$ concentrations was tested for antibacterial capability against Staphylococcus aureus with Kirby Bauer disc diffusion method, with Amoxicillin as the positive control and 10\% Dimethyl Sulfoxide. This data was statistically analyzed with One Way Anova. Ethanol extract of Kalanduyung leaves can inhibit Staphylococcus aureus with each inhibition zone diameter was $6.875 \mathrm{~mm}, 8.5$ $\mathrm{mm}, 10.175 \mathrm{~mm}$, and $14.925 \mathrm{~mm}$. The ethanol extract of Kalanduyung leaves can inhibit the growth of Staphylococcus aureus bacteria.
\end{abstract}

Keywords: Staphylococcus aureus, Kalanduyung leaf (Guazuma ulmifolia Lam.), Kirby-Bauer disk

\section{PENDAHULUAN}

Pneumonia merupakan penyakit berbahaya yang dapat disebabkan oleh virus atau bakteri, salah satunya adalah bakteri Staphylococcus aureus. Pneumonia merupakan infeksi akut pada parenkim paru, bronkiolus respiratorius dan alveoli, menimbulkan konsolidasi jaringan paru sehingga dapat mengganggu pertukaran oksigen dan karbon dioksida di paru-paru (IDI, 2014). Menurut World Health Organization (WHO) pada tahun 2014, kematian pneumonia di Indonesia pada tahun 2013 berada pada urutan ke-8, dengan skor sebesar 22.000. Menurut hasil Riset Kesehatan Dasar (Riskesdas) tahun 2013, lima 
provinsi yang mempunyai insiden pneumonia balita tertinggi adalah Nusa Tenggara Timur $(38,5 \%)$, Aceh (35,6\%), Bangka Belitung $(34,8 \%)$, Sulawesi Barat $(34,8 \%)$, dan Kalimantan Tengah $(32,7 \%)$. Insiden tertinggi pneumonia balita terdapat pada kelompok umur $12-23$ bulan $(21,7 \%)$ (BPPK Kemenkes RI, 2013). Hasil tersebut membuktikan bahwa kecenderungan penyakit yang disebabkan bakteri masih dialami oleh penduduk Indonesia. Salah satunya adalah karena infeksi Staphylococcus aureus, yaitu penyebab penyakit pneumonia.

Staphylococcus aureus adalah spesies yang sering menginfeksi karena dapat ditemukan di udara dan lingkungan sekitar (Kenneth, 2011). SENTRY Antimicrobial Surveillance Program dari tahun 1997 sampai 2001 menyatakan Staphylococcus aureus adalah patogen yang paling umum diisolasi di Amerika Serikat dan di Eropa, serta organisme paling umum kedua di Amerika Latin (Tong et al., 2015). Pada penelitian di Bali, ditemukan pertumbuhan beberapa jenis mikroorganisme, salah satunya adalah Staphylococcus aureus (1,4\%), pada biakan darah subjek pneumonia (Purniti et al., 2011).

Staphylococcus aureus merupakan flora normal pada saluran nafas atas, namun dapat menyebabkan infeksi jika jumlahnya melebihi jumlah normal (>110 CFU/ml) (Rondhianto et al., 2016). Namun, Staphylococcus aureus menjadi masalah yang sangat serius karena terjadinya peningkatan resistensi bakteri ini terhadap berbagai jenis antibiotik, dikarenakan penggunaannya yang tidak sesuai. Maka banyak penelitian-penelitian terkait tanaman-tanaman yang memiliki potensi antibakteri. Salah satu tanaman yang memiliki potensi antibakteri tersebut adalah Kalanduyung (Guazuma ulmifolia Lam.) atau sering disebut dengan Jati Belanda. Penelitian yang dilakukan Rahmawati pada tahun 2014 menyatakan bahwa daun Jati Belanda memiliki aktivitas antibakteri terhadap bakteri gram positif, yaitu Bacillus cereus dan Escherichia coli. Tumbuhan Kalanduyung (Guazuma ulmifolia Lam.) merupakan tanaman kelas Dicotyledoneae dan dapat dijumpai di Kalimantan Tengah, karena sifatnya yang dapat tumbuh di daerah tropis. Berdasarkan studi pendahuluan yaitu dalam bentuk kuisioner, Kalanduyung digunakan beberapa masyarakat sebagai pengobatan infeksi saluran pernafasan. Berdasarkan hasil fitokimia yang telah dilakukan, daun dari tanaman Kalanduyung mengandung senyawa-senyawa kimia seperti alkaloid, flavonoid, saponin, tanin, dan steroid. Adanya kandungan senyawa yang dapat bekerja sebagai antimikroba atau antibakteri membuat daun Kalanduyung berpotensi menjadi antibakteri bagi bakteri Staphylococcus aureus.

Berdasarkan uraian di atas, maka perlu dilakukan uji aktivitas antibakteri daun Kalanduyung (Guazuma ulmifolia Lam.) terhadap Staphylococcus aureus dalam rangka membuktikan adanya kandungan antibakteri dalam daun Kalanduyung. Penelitian ini dilakukan secara in vitro dengan metode difusi cakram Kirby Bauer, kemudian daya hambat diukur dengan menggunakan jangka sorong terhadap pertumbuhan Staphylococcus aureus.

\section{METODOLOGI}

\section{Jenis dan Rancangan Penelitian}

Penelitian ini merupakan penelitian true experimental design. Rancangan penelitian menggunakan post test-only control group design. 


\section{Sampel dan Teknik Pengambilan Sampel}

Pengambilan sampel dilakukan dengan teknik randomisasi, yaitu koloni Staphylococcus aureus yang tumbuh pada media secara acak. Sampel diambil menggunakan jarum inokulasi (ose) (Mpila et al., 2012).

Perhitungan besar sampel untuk setiap perlakuan ditentukan dengan menggunakan rumus Federer, yaitu : $(\mathrm{t}-1)(\mathrm{n}-1) \geq 15$ dimana, $\mathrm{t}=$ banyaknya perlakuan yang dicoba, $\mathrm{n}$ = banyaknya sampel (Sukandar et al., 2009). Jadi, jumlah perlakuan ada 4, yaitu perlakuan pada konsentrasi $20 \%$, $40 \%, 60 \%$, dan $80 \%$, ditambah dengan 1 perlakuan untuk kontrol positif dan 1 perlakuan untuk kontrol negatif, dengan pengulangan sebanyak 6 kali. Jadi didapatkan total sebanyak 24 kali perlakuan.

\section{Prosedur}

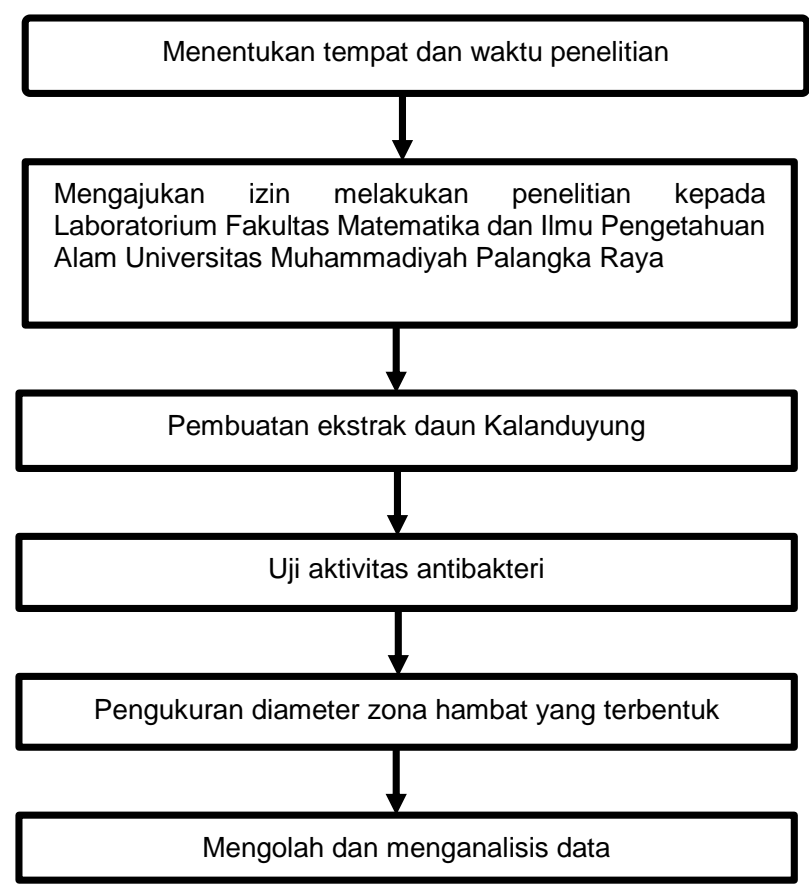

\section{HASIL DAN PEMBAHASAN}

Tumbuhan Kalanduyung yang diambil dari Jalan Yos Sudarso XVII, Palangka Raya diuji fitokimia di
Laboratorium Fakultas Kedokteran Bagian KimiaBiokimia Universitas Lambung Mangkurat. Hasil uji fitokimia dari laboratorium tersebut menyatakan bahwa daun tumbuhan tersebut memiliki kandungan sebagai berikut:

Tabel I. Hasil Uji Fitokimia

\begin{tabular}{cc}
\hline Kandungan & Kadar \\
\hline Saponin & $9,010 \pm 0,257$ \\
Alkaloid & $47,192 \pm 0,447$ \\
Flavonoid & $2,852 \pm 0,055$ \\
Steroid & $43,164 \pm 0,276$ \\
Tanin & $16,138 \pm 0,0405$ \\
\hline
\end{tabular}

Dari hasil uji fitokimia yang didapatkan menunjukkan bahwa kandungan terbanyak yang terdapat pada daun Kalanduyung adalah alkaloid. Daun Kalanduyung (Guazuma ulmifolia Lam.) yang diteliti adalah daun yang memenuhi kriteria yang telah ditetapkan sebelumnya yaitu daun yang masih melekat dengan batang dengan kriteria masih berwarna hijau secara keseluruhan dibagian atasnya dan tidak ada bagian daunnya yang terpotong atau dimakan hewan. Kemudian daun diekstraksi dengan metode maserasi dengan hasil seperti yang tercantum Tabel II.

Tabel II. Hasil Pengukuran berbagai Tahap Ekstraksi

\begin{tabular}{cccc}
\hline $\begin{array}{c}\text { Bobot Daun } \\
\text { Kalanduyung } \\
\text { segar }(\mathrm{kg})\end{array}$ & $\begin{array}{c}\text { Bobot } \\
\text { Simplisia } \\
(\mathrm{g})\end{array}$ & $\begin{array}{c}\text { Volume } \\
\text { filtrat } \\
(\mathrm{mL})\end{array}$ & $\begin{array}{c}\text { Bobot } \\
\text { Ekstrak } \\
\text { Kental }(\mathrm{g})\end{array}$ \\
\hline 4 & 600 & 6134 & 147,6376 \\
\hline
\end{tabular}

Hasil dari ekstrak etanol daun Kalanduyung (Guazuma ulmifolia Lam.) yang dibentuk dalam berbagai konsentrasi, baik konsentrasi $20 \%, 40 \%$, $60 \%$, dan $80 \%$, terhadap pertumbuhan bakteri Staphylococcus aureus yang ditumbuhkan pada media Mueller Hinton Agar mampu membentuk diameter zona hambat dalam pertumbuhan bakteri tersebut. Hal ini dapat terlihat dari hasil yang tercantum pada Tabel III dibawah ini. 
Tabel III. Hasil Pengukuran Diameter Zona Hambat yang terbentuk pada Media Mueller Hinton Agar

\begin{tabular}{ccccccc}
\hline $\begin{array}{c}\text { Diameter } \\
\text { Zona }\end{array}$ & \multirow{2}{*}{$\begin{array}{c}\text { Kontrol } \\
\text { Hambat }\end{array}$} & $\begin{array}{c}\text { Negatif } \\
(\mathrm{mm})\end{array}$ & $\begin{array}{c}\text { Kontrol } \\
\text { Positif }\end{array}$ & \multicolumn{3}{c}{$\begin{array}{c}\text { Diameter Zona Hambat tiap } \\
\text { Konsentrasi Ekstrak (mm) }\end{array}$} \\
\cline { 5 - 8 } & & $(\mathrm{mm})$ & $20 \%$ & $40 \%$ & $60 \%$ & $80 \%$ \\
\hline I & 0 & 25,9 & 7,7 & 8,9 & 11,9 & 12,8 \\
II & 0 & 24,2 & 5,1 & 7,8 & 10,3 & 16,7 \\
III & 0 & 25,8 & 6,8 & 8,6 & 8,7 & 15,3 \\
IV & 0 & 30,5 & 7,9 & 8,7 & 9,8 & 14,9 \\
\hline Rata-rata & 0 & 26,6 & 6,9 & 8,5 & 10,2 & 14,9 \\
\hline
\end{tabular}

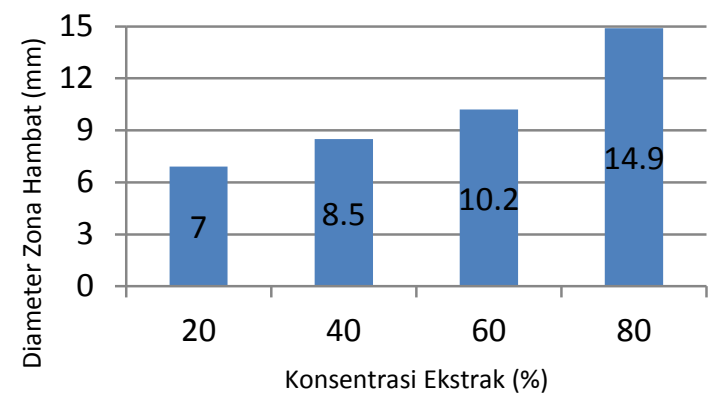

Gambar 1. Rata-rata Diameter Zona Hambat Pertumbuhan Staphylococcus aureus oleh Ekstrak Etanol Daun Kalanduyung

Dari Tabel III dan Gambar 1 di atas dapat dilihat bahwa masing-masing konsentrasi dapat membentuk zona hambat pada media Mueller Hinton Agar yang telah ditumbuhkan bakteri Staphylococcus aureus, yaitu konsentrasi $20 \%$ dengan rata-rata ukuran zona hambat yang terbentuk sebesar $6,9 \mathrm{~mm}, 40 \%$ sebesar $8,5 \mathrm{~mm}$, $60 \%$ sebesar $10,2 \mathrm{~mm}$, dan $80 \%$ sebesar $14,9 \mathrm{~mm}$. Dari keempat konsentrasi tersebut terlihat bahwa pada konsentrasi $80 \%$ zona hambat yang terbentuk adalah zona hambat yang terbesar, hal ini dapat terlihat dari rata-rata zona hambat yang terbentuk yaitu $14,9 \mathrm{~mm}$.

Data penelitian yang didapat dilakukan uji statistic berupa uji One Way Anova, sebelum dilakukan uji tersebut maka harus dilakukan uji normalitas untuk memastikan data berdistribusi normal dan uji varians karena data harus homogen.
Tabel IV. Uji Normalitas Saphiro-Wilk

\begin{tabular}{cc}
\hline Uji saphiro-wilk & Sig \\
\hline Zona hambatan oleh ekstrak daun Kalanduyung & 0,162 \\
\hline
\end{tabular}

Tabel IV merupakan hasil uji normalitas saphirowilk yang menunjukkan bahwa data memiliki nilai $\mathrm{p}$ $>0,05$ berarti data tersebut terdistribusi normal. Data yang berdistribusi normal merupakan syarat dari data parametrik sehingga dapat dilakukan analisis homogenitas dan One Way Anova.

Tabel V. Uji Varians Data

\begin{tabular}{cc}
\hline Uji Varians & Sig \\
\hline Zona hambatan oleh ekstrak daun Kalanduyung & 0,553 \\
\hline
\end{tabular}

Tabel $\vee$ menunjukkan bahwa nilai $p>0,05$, yang artinya data yang ada dalam penelitian ini memiliki varian yang sama sehingga dapat dilakukan pengujian dengan menggunakan One Way Anova.

Tabel VI. Uji One Way Anova

\begin{tabular}{cc}
\hline Uji One Way Anova & Sig \\
\hline Kelompok perlakuan ekstrak daun Kalanduyung & 0,000 \\
\hline
\end{tabular}

Tabel VI menunjukkan bahwa hasil uji One Way Anova terhadap kelompok perlakuan ekstrak etanol daun Kalanduyung memiliki nilai $p=0,000$. Karena nilai $p<0,05$, maka nilai rata-rata antar kelompok perlakuan ekstrak etanol daun Kalanduyung adalah berbeda bermakna. Untuk mengetahui kelompok perlakuan yang memiliki perbedaan bermakna tersebut, maka selanjutnya dilakukan analisis post-hoc. 
Tabel VII. Uji Analisis Post-Hoc

\begin{tabular}{|c|c|c|c|c|c|c|}
\hline & $20 \%$ & $40 \%$ & $60 \%$ & $80 \%$ & $\begin{array}{c}\text { Kontrol } \\
\text { Positif }\end{array}$ & $\begin{array}{l}\text { Kontrol } \\
\text { Negatif }\end{array}$ \\
\hline $20 \%$ & - & 0,144 & $0,006^{\star}$ & $0,000^{*}$ & $0,000^{\star}$ & $0,000^{*}$ \\
\hline $40 \%$ & 0,144 & - & 0,133 & $0,000^{*}$ & $0,000^{\star}$ & $0,000^{*}$ \\
\hline $60 \%$ & $0,006^{*}$ & 0,133 & - & $0,000^{*}$ & $0,000^{*}$ & $0,000^{*}$ \\
\hline $80 \%$ & $0,000^{*}$ & $0,000^{*}$ & $0,000^{*}$ & - & $0,000^{*}$ & $0,000^{*}$ \\
\hline $\begin{array}{c}\text { Kontrol } \\
\text { Positif }\end{array}$ & $0,000^{*}$ & $0,000^{*}$ & $0,000^{*}$ & $0,000^{*}$ & - & $0,000^{*}$ \\
\hline $\begin{array}{l}\text { Kontrol } \\
\text { Negatif }\end{array}$ & $0,000^{\star}$ & $0,000^{*}$ & $0,000^{*}$ & $0,000^{*}$ & $0,000^{*}$ & - \\
\hline
\end{tabular}

Tabel VII merupakan hasil uji Post-Hoc yang menunjukkan jika data memiliki nilai $\mathrm{p}<0,05$ berarti data tersebut signifikan atau berbeda bermakna dengan konsentrasi lain. Jika $p>0,05$, maka data tersebut tidak signifikan atau tidak berbeda bermakna dengan konsentrasi lain. Uji Post-Hoc menunjukkan diameter zona hambat bakteri Staphylococcus aureus untuk konsentrasi ekstrak 20\% tidak memiliki perbedaan bermakna dengan konsentrasi $40 \%$, tetapi terdapat perbedaan bermakna pada konsentrasi $60 \%, 80 \%$, kontrol positif, dan kontrol negatif. Untuk konsentrasi $40 \%$, tidak memiliki perbedaan bermakna dengan konsentrasi $20 \%$ dan $60 \%$, tetapi berbeda bermakna dengan konsentrasi $60 \%$, 80\%, kontrol positif, dan kontrol negatif. Konsentrasi $60 \%$ tidak memiliki perbedaan bermakna dengan konsentrasi 40\%, namun berbeda bermakna dengan konsentrasi $20 \%, 80 \%$, dan seluruh kontrol. Sedangkan konsentrasi $80 \%$ berbeda bermakna dengan semua konsentrasi, baik 20\%, 40\%,60\%, dan seluruh kontrol.

Pada hasil Tabel VII terlihat bahwa masing-masing kelompok konsentrasi ekstrak etanol dari daun tumbuhan Kalanduyung dapat membentuk zona hambat. Konsentrasi 20\% dapat membentuk zona hambat dengan rata-rata ukuran zona hambat yang terbentuk sebesar $6,9 \mathrm{~mm}$. Konsentrasi $40 \%$ dapat membentuk zona hambat dengan rata-rata sebesar $8,5 \mathrm{~mm}$. Konsentrasi $60 \%$ dapat membentuk zona hambat dengan rata-rata sebesar 10,2 mm. Konsentrasi $80 \%$ dapat membentuk zona hambat dengan rata-rata sebesar $14,9 \mathrm{~mm}$. Pada kontrol positif didapatkan zona hambat dengan rata-rata 26,6 $\mathrm{mm}$. sedangkan pada kontrol negatif yang berupa dimethyl sulfoxide (DMSO) tidak membentuk zona hambat pada medium yang ditumbuhi Staphylococcus aureus. Hal ini membuktikan bahwa kandungan ekstrak daun Kalanduyung dapat menghambat pertumbuhan Staphylococcus aureus.

Daun Kalanduyung memiliki kandungan saponin, tanin, alkaloid, flavonoid, dan steroid yang merupakan senyawa antibakteri. Hal ini didukung oleh penelitian Supomo tahun 2015, yang menyatakan bahwa kulit buah manggis yang memiliki kandungan saponin, tanin, alkaloid, flavonoid, dan steroid, memiliki potensi antibakteri. Mekanisme kerja saponin sebagai antibakteri adalah menurunkan tegangan permukaan sehingga mengakibatkan naiknya permeabilitas atau kebocoran sel dan mengakibatkan senyawa intraseluler akan keluar. Tanin memiliki aktifitas antibakteri yang berhubungan dengan kemampuannya untuk menginaktifkan adhesin sel mikroba juga menginaktifkan enzim, dan mengganggu transport protein pada lapisan dalam sel (Ngajow et al., 2013). Mekanisme kerja alkaloid sebagai antibakteri diprediksi melalui penghambatan sintesis dinding sel yang akan menyebabkan lisis pada sel sehingga sel akan mati (Nikham, 2012). Flavonoid diketahui memiliki sifat antibakteri dimana mekanisme kerjanya adalah membentuk senyawa kompleks dengan 
protein ekstraseluler dan terlarut sehingga dapat merusak membran sel bakteri dan diikuti dengan keluarnya senyawa intraseluler (Darmawati et al., 2015). Mekanisme kerja steroid dalam menghambat mikroba adalah dengan merusak membran plasma sel mikroba, sehingga menyebabkan bocornya sitoplasma keluar sel yang selanjutnya menyebabkan kematian sel (Wiyanto, 2010). Berdasarkan mekanisme kerjanya, antibakteri dibedakan menjadi bakteriostatik dan bakterisidal. Antibakteri bakteriostatik adalah zat yang bekerja menghambat pertumbuhan bakteri, sedangkan antibakteri bakterisida adalah zat yang bekerja mematikan bakteri.

Pada tabel III menunjukkan diameter zona hambat Staphylococcus aureus untuk kontrol negatif, terlihat adanya perbedaan yang bermakna terhadap kontrol positif dan berbagai konsentrasi ekstrak etanol daun Kalanduyung, yaitu $20 \%, 40 \%$, $60 \%$, dan $80 \%$. Kontrol negatif yang digunakan adalah DMSO yang menunjukkan tidak adanya zona hambat. Pelarut DMSO merupakan pelarut organik dan tidak bersifat bakterisidal (Assidqi et al., 2012). Hal ini menandakan bahwa DMSO tidak memiliki aktivitas anti bakteri, sehingga dapat dipastikan aktivitas antibakteri yang dihasilkan tidak dipengaruhi secara langsung oleh DMSO (Amalia et al., 2016). Selain itu, DMSO juga merupakan pelarut yang dapat melarutkan hampir semua senyawa polar maupun non polar.

Kontrol positif menunjukkan perbedaan yang bermakna dengan kontrol negatif dan berbagai konsentrasi ekstrak etanol daun Kalanduyung, karena menghasilkan aktivitas antibakteri dengan diameter zona hambat paling besar terhadap bakteri uji, yaitu 26,6 mm. Antibiotik yang digunakan sebagai kontrol positif adalah amoksisilin yang memiliki spektrum luas. Zona hambat dari perlakuan amoksisilin pada penelitian ini adalah sebesar 26,6 mm yang menunjukan bahwa ampisilin yang diuji adalah sensitif berdasarkan standart CLSI. Mekanisme kerja dari amoksisilin adalah dengan menghambat biosintesis dari mukopeptida dinding sel bakteri saat bakteri bermultiplikasi (Kaur et al., 2011). Amoksisilin, memiliki senyawa-senyawa kimia yang lebih kuat dalam menghambat pertumbuhan bakteri Staphylococcus aureus dibandingkan dengan ekstrak daun Kalanduyung.

Berdasarkan hasil pengukuran diameter zona hambat menunjukkan bahwa ekstrak etanol daun Kalanduyung memiliki daya hambat yang sedang sampai kuat terhadap Staphylococcus aureus. Konsentrasi $20 \%$ dan $40 \%$ memiliki daya hambat sedang, sedangkan konsentrasi $60 \%$ dan $80 \%$ memiliki daya hambat yang kuat. Penentuan kriteria ini berdasarkan Davis dan Stout (1971) yang melaporkan bahwa ketentuan kekuatan daya antibakteri sebagai berikut: daerah hambatan $\geq 20$ $\mathrm{mm}$ termasuk sangat kuat, daerah hambatan 10 $20 \mathrm{~mm}$ kategori kuat, daerah hambatan 5-10 mm kategori sedang, dan daerah hambatan $5 \mathrm{~mm}$ atau kurang termasuk kategori lemah (Mpila et al., 2012).

Pada tabel III terlihat bahwa diameter zona hambat yang terbesar dan yang paling mendekati diameter zona hambat yang dibentuk kontrol positif dimiliki oleh konsentrasi $80 \%$ sebesar $14,9 \mathrm{~mm}$ dan terkecil yaitu konsentrasi $20 \%$ sebesar $6,9 \mathrm{~mm}$. Hal tersebut membuktikan bahwa semakin tinggi konsentrasi ekstrak daun Kalanduyung, maka semakin baik untuk menghambat pertumbuhan Staphylococcus aureus. Menurut penelitian yang 
dilakukan Rastina et al pada tahun 2015, konsentrasi efektif adalah konsentrasi yang daya antibakterinya dikategorikan kuat untuk membentuk zona hambat terbesar. Maka dapat disimpulkan, maka konsentrasi $80 \%$ ekstrak etanol daun Kalanduyung merupakan konsentrasi efektif dalam menghambat pertumbuhan Staphylococcus aureus, terlihat dari besarnya diameter zona hambat yang terbentuk. Hal tersebut didukung oleh Pelczar dan Chan (1988) yang menyatakan bahwa salah satu faktor yang mempengaruhi akivitas bahan antimikroba, yaitu konsentrasi bahan antimikroba. Daya hambat yang dihasilkan oleh bahan antimikroba akan semakin tinggi apabila konsentrasinya juga tinggi (Amrie et al., 2014). Namun, sebaiknya untuk mengetahui konsentrasi efektif dari suatu zat antimikroba perlu dilakukan uji aktivitas antibakteri dengan metode dilusi, sehingga didapatkan konsentrasi hambat minimum dari ekstrak tersebut (Soleha, 2015).

Hasil analisis data diameter zona hambat yang terbentuk dengan One Way Anova menunjukkan nilai signifikansi 0,000 , yang berarti $p<0,05$. Nilai $\mathrm{p}<0,05$ menunjukkan adanya perbedaan bermakna rata-rata antar kelompok konsentrasi pada penelitian ini. Setelah dilakukan uji Post-Hoc, ditemukan bahwa untuk konsentrasi ekstrak 20\% tidak memiliki perbedaan bermakna dengan konsentrasi $40 \%$, tetapi terdapat perbedaan bermakna pada konsentrasi $60 \%$ dan $80 \%$. Untuk konsentrasi $40 \%$, tidak memiliki perbedaan bermakna dengan konsentrasi $20 \%$ dan $60 \%$, tetapi berbeda bermakna dengan konsentrasi $80 \%$. Konsentrasi $60 \%$ tidak memiliki perbedaan bermakna dengan konsentrasi 40\%, namun berbeda bermakna dengan konsentrasi $20 \%$ dan $80 \%$. Sedangkan konsentrasi $80 \%$ berbeda bermakna dengan semua konsentrasi, baik $20 \%$, $40 \%$, dan $60 \%$.

Secara keseluruhan pada penelitian ini pengulangan dalam berbagai konsentrasi menunjukkan aktivitas antibakteri dengan terbentuknya zona hambat. Hal ini membuktikan hipotesis dalam penelitian ini bahwa ekstrak etanol daun Kalanduyung (Guazuma ulmifolia Lam.) menghambat pertumbuhan Staphylococcus aureus dengan metode Kirby-Bauer.

\section{KESIMPULAN}

Berdasarkan uji fitokimia yang dilakukan, kandungan terbanyak pada daun Kalanduyung (Guazuma ulmifolia Lam.) adalah alkaloid. Ekstrak etanol daun Kalanduyung (Guazuma ulmifolia Lam.) dapat menghambat pertumbuhan bakteri Staphylococcus aureus pada konsentrasi uji $20 \%$, $40 \%, 60 \%$ dan $80 \%$. Konsentrasi paling efektif ekstrak etanol daun Kalanduyung (Guazuma ulmifolia Lam.) yang memiliki diameter zona hambat terbesar terhadap pertumbuhan bakteri Staphylococcus aureus adalah konsentrasi $80 \%$ dengan rata-rata diameter zona hambat yang terbentuk sebesar $14,9 \mathrm{~mm}$.

\section{DAFTAR PUSTAKA}

Ikatan Dokter Indonesia. Panduan Praktik Klinis Bagi Dokter di Fasilitas Pelayanan Kesehatan Primer. Jakarta. 2014:381.

Badan Penelitian dan Pengembangan Kesehatan Kementerian Kesehatan RI. Riset Kesehatan Dasar 2013. Jakarta. 2013.

Kenneth DS. Rangkuman Kasus Klinik Mikrobiologi dan Penyakit Infeksi. Jakarta: Karisma Publishing Group. 2011.

Tong SYC, Davis JS, Eichenberger E, Holland TL, Fowler VG. Staphylococcus aureus 
Infections: Epidemiology, Pathophysiology, Clinical Manifestations, and Management. Journal ASM. 2015.

Purniti PS, Subanada IB, Kari IK, Arhana BNP, Iswari IS, Tarini NMA. Surveilan Pneumokokus dan Dampak Pneumonia pada Anak Balita. Sari Pediatri. 2011;12(5):359-364.

Rondhianto, Kurniawati D, Vidiany AK. Batuk Efektif dan Napas Dalam untuk Menurunkan Kolonisasi Staphylococcus aureus dalam Sekret Pasien Pasca Operasi dengan Anastesi Umum di RSD Dr. Soebandi Jember. NurseLine Journal. 2016;1(1):151158.

Rahmawati. Uji Aktivitas Antibakteri Ekstrak Etanol Daun Jati Belanda (Guazuma ulmifolia Lamk) terhadap Bakteri Penyebab Diare (Bacillus cereus dan Escherichia coli) [Skripsi]. Bandung: Fakultas Matematika dan IImu Pengetahuan Alam Universitas Islam Bandung. 2014.

Mpila DA, Fatimawali, Wiyono WI. Uji Aktivitas Antibakteri Ekstrak Etanol Daun Mayana (Coleus atropurpureus [L] Benth) terhadap Staphylococcus aureus, Escherichia coli dan Pseudomonas aeruginosa secara InVitro. Manado: Fakultas Matematika dan IImu Pengetahuan Alam Universitas Sam Ratulangi. 2012;1(1):13-21.

Sukandar EY, Elfahmi, Nurdewi. Pengaruh Pemberian Ekstrak Air Daun Jati Belanda (Guazuma Ulmifolia Lamk.) terhadap Kadar Lipid Darah pada Tikus Jantan. Bandung: Institut Teknologi Bandung. JKM. 2009;8(2):102-112.

Supomo, Syamsul ES, Rukmana. Uji Aktivitas Anti Bakteri Ekstrak Etanol Kulit Buah Manggis (Garcinia mangostana L.) terhadap Bakteri Staphylococcus epidermidis ATCC 49461. Jurnal IImu Kesehatan. 2015;3(2).

Ngajow M, Abidjulu J, Kamu VS. Pengaruh Antibakteri Ekstrak Kulit Batang Matoa (Pometia pinnata) terhadap Bakteri Staphylococcus aureus secara In vitro. Jurnal MIPA UNSRAT Online. 2013;2(2):182-132.
Nikham, Basjir TE. Uji Bahan Baku Antibakteri dari Buah Mahkota Dewa (Phaleria Macrocarpa (Scheff) Boerl.) Hasil Iradiasi Gamma dan Antibiotik terhadap Bakteri Patogen. Serpong: Prosiding Pertemuan IImiah IImu Pengetahuan dan Teknologi Bahan. 2012.

Darmawati AASK, Bawa IGAG, Suirta IW. Isolasi dan Identifikasi Senyawa Golongan Flavonoid pada Daun Nangka (Artocarpus heterophyllus Lmk) dan Aktivitas Antibakteri terhadap Bakteri Staphylococcus aureus. Jurnal Kimia. 2015;9(2):203-210.

Wiyanto DB. Uji Aktivitas Antibakteri Ekstrak Rumput Laut Kappaphycus alvarezii dan Eucheuma denticullatum terhadap Bakteri Aeromonas hydrophila dan Vibrio harveyii. Jurnal Kelautan. 2010;3(1):1-17.

Assidqi K, Tjahjaningsih W, Sigit S. Potensi Ekstrak Daun Patikan Kebo (Euphorbia hirta) sebagai Antibakteri terhadap Aeromonas hydrophila secara In Vitro. Journal of Marine and Coastal Science. 2012;1(2):113 - 124.

Amalia S, Wahdaningsih S, Untari EK. Uji Aktivitas Antibakteri Fraksi n-Heksan Kulit Buah Naga Merah (Hylocereus polyrhizus Britton \& Rose) terhadap Bakteri Staphylococcus aureus ATCC 25923. Pontianak: Fakultas Kedokteran Universitas Tanjungpura. Jurnal Fitofarmaka Indonesia. 2016;1(2):61-64.

Kaur SP, Rao R, Nanda S. Amoxicillin: A Broad Spectrum Antibiotic. India. 2011;3(3):30-37.

Rastina, Sudarwanto M, Wientarsih I. Aktivitas Antibakteri Ekstrak Etanol Daun Kari (Murraya koenigii) terhadap Staphylococcus aureus, Escherichia coli, dan Pseudomonas sp. Jurnal Kedokteran Hewan. 2015;9(2):185188.

Amrie AGA, Ivan, Anam S, Ramadhanil. Uji Efektifitas Ekstrak Daun dan Akar Harrisonia perforata Merr. terhadap Pertumbuhan Bakteri Vibrio cholerae. Online Jurnal of Natural Science. 2014;3(3):331-340.

Soleha TU. Uji Kepekaan terhadap Antibiotik. Fakultas Kedokteran Universitas Lampung. 2015;5(9):119-123. 